\title{
Havayolu Taşımacılığında Hizmet Kalitesinin Kurumsal İmaj, Müşteri Memnuniyeti ve Müşteri Sadakati Üzerindeki Etkisi \\ (The Effect of Service Quality on Airline Transportation on Corporate Image, Customer Satisfaction and Customer Loyalty)
}

\section{Gözde YANGINLAR iD a Fatih TUNA (iD b}

a İstanbul Ticaret Üniversitesi, İşletme Fakültesi, İşletme Bölümü, İstanbul, Türkiye.gyanginlar@ticaret.edu.tr

b Beykent Üniversitesi, Sosyal Bilimler Enstitüsü, İstanbul, Türkiye. fthtuna@hotmail.com

\begin{tabular}{|c|c|}
\hline MAKALE BİLGİSİ & ÖZET \\
\hline $\begin{array}{l}\text { Anahtar Kelimeler: } \\
\text { Havayolu Taşımacılı̆̆ } \\
\text { Hizmet Kalitesi } \\
\text { Kurumsal İmaj } \\
\text { Müşteri Memnuniyeti } \\
\text { Müşteri Sadakati. }\end{array}$ & $\begin{array}{l}\text { Amaç - Havayolu taşımacılık sektöründe işletme sayılarının ve filo büyüklüklerinin artması ve yeni } \\
\text { uçuş noktalarının açlması sonucu havayolu hizmet kalitesi en önemli rekabet unsuru haline } \\
\text { gelmiş̧ir. Küreselleşmenin etkisiyle müş̧eri ihtiyaç \& isteklerinin değişmesi, bilgi teknolojilerinin } \\
\text { etkinleşmesi müşteri memnuniyeti ve sadakatini sağlamayı daha da zorlaştırmaktadır. Bu } \\
\text { çalışmanın amacı, havayolu taşımacılığında hizmet kalitesinin kurumsal imaj, müşteri } \\
\text { memnuniyeti ve müşteri sadakati üzerindeki etkilerini belirlemektir. Yapılan literatür taramasında, } \\
\text { havayolu taşımacılığında hizmet kalitesinin kurumsal imaj, müşteri memnuniyeti ve müşteri } \\
\text { sadakati üzerindeki etkisini inceleyen bir çalışmaya rastlanılamamı̧şır. Bu çalışma ile literatüre } \\
\text { katkı sağlanması hedeflenmektedir. }\end{array}$ \\
\hline $\begin{array}{l}\text { Gönderilme Tarihi } 5 \text { Kasım } \\
2019 \\
\text { Revizyon Tarihi } 19 \text { Ocak } 2020 \\
\text { Kabul Tarihi } 7 \text { Şubat } 2020\end{array}$ & $\begin{array}{l}\text { Yöntem - Araştırmanın evrenini, uluslararası tanınırlığa sahip bir havayolu işletmesinin İstanbul } \\
\text { kalkışlı } 260 \text { dış hat yolcuları oluşturmaktadır. Anket formlarının uygulandığı dış hatlarda farklı } \\
\text { destinasyonlara gidecek yolcuların bulunması ve yolcuların farklı özelliklerde olması örneklem } \\
\text { evreninin temsil yeteneğini güçlendirmektedir. Araştırmaya gönüllü olarak katılan havayolu } \\
\text { taşımacılığını tercih eden dış hat yolcularına ilişkin veriler, yüz yüze anket yöntemi ile elde } \\
\text { edilmiştir. SPSS paket programından yararlanılarak istatistiksel analizler yapılmıştır. }\end{array}$ \\
\hline \multirow{2}{*}{$\begin{array}{l}\text { Makale Kategorisi: } \\
\text { Araştırma Makalesi }\end{array}$} & $\begin{array}{l}\text { Bulgular - Araştırma bulguları, havayolu hizmet kalitesinin alt boyutlarından güven ve empatinin } \\
\text { kurumsal imajı pozitif yönde etkilediği tespit edilmiştir. Havayolu taşımacılığında müşteri } \\
\text { memnuniyetinin ve sadakatinin sağlamasında fiziki görünüm, güvenirlilik ve empati boyutlarının } \\
\text { etkili olduğu sonucuna ulaşılmıştır. }\end{array}$ \\
\hline & $\begin{array}{l}\text { Tartışma - Çalışma hizmet kalitesi, kurumsal imaj, müşteri memnuniyeti ve müşteri sadakati ilgili } \\
\text { literatürde daha önce yapılan çalışmaları destekler niteliktedir. Havayolu hizmet kalitesinin alt } \\
\text { faktörlerinden hevesliliğin kurumsal imaj, müşteri memnuniyeti ve müşteri sadakati üzerinde } \\
\text { belirgin bir düzenleyici etkisinin olacağı tahmin edilmiştir. Ancak araştırmada elde edilen } \\
\text { sonuçlarda pozitif bir etkisi olmadığını göstermektedir. }\end{array}$ \\
\hline
\end{tabular}

\begin{tabular}{|c|c|}
\hline ART & ABSTI \\
\hline & \multirow{7}{*}{$\begin{array}{l}\text { Purpose - Airline service quality has become the most important element of competition in the air } \\
\text { transport sector as a result of the increase in the number of enterprises and fleet sizes and the } \\
\text { opening of new destinations. Changing the needs and desires of the customers with the effect of } \\
\text { globalization and the activation of information technologies make it more difficult to ensure } \\
\text { customer satisfaction and loyalty. The aim of this study is to determine the effects of service quality } \\
\text { on corporate image, customer satisfaction and customer loyalty. In the literature review, a study } \\
\text { examining the effect of service quality on corporate image, customer satisfaction and customer } \\
\text { loyalty could not be found. This study aims to contribute to the literature. }\end{array}$} \\
\hline & \\
\hline Servi & \\
\hline Corpc & \\
\hline & \\
\hline Customer Satisfaction. & \\
\hline & \\
\hline Received 5 November 2019 & \multirow{5}{*}{$\begin{array}{l}\text { Design/methodology/approach - The population of the study consists of } 260 \text { international } \\
\text { passengers departing from Istanbul of an internationally recognized airline. The presence of } \\
\text { passengers to different destinations on the international lines where the questionnaire forms are } \\
\text { applied and the different characteristics of the passengers reinforce the representation ability of the } \\
\text { sample universe. The data on the international passengers who prefer to participate in the study } \\
\text { voluntarily were obtained through a face-to-face survey. SPSS software was used for statistical } \\
\text { analysis. }\end{array}$} \\
\hline Revised 19 January 2020 & \\
\hline Accepted 7 Fer & \\
\hline Article Clas & \\
\hline & \\
\hline
\end{tabular}

Findings - The findings of the study revealed that trust and empathy, one of the sub-dimensions of airline service quality, positively affected the corporate image. Physical appearance, reliability and

\section{Önerilen Atıf/Suggested Citation}

Yangınlar, G., Tuna, F. (2020). Havayolu Taşımacılığında Hizmet Kalitesinin Kurumsal İmaj, Müşteri Memnuniyeti ve Müşteri Sadakati Üzerindeki Etkisi, İşletme Araştırmaları Dergisi, 12 (1), 173-187. 
empathy dimensions were found to be effective in achieving customer satisfaction and loyalty in air transportation.

Discussion - The study supports previous studies in the literature related to service quality, corporate image, customer satisfaction and customer loyalty. The willingness, one of the sub-factors of airline service quality, was predicted to have a significant regulatory impact on corporate image, customer satisfaction and customer loyalty. However, the results obtained in the study showed no positive effect.

\section{Giriş̧}

Havayolu taşımacılığının dinamik, çok hızlı gelişen bir yapıya sahip olması ve yakıt maliyetlerindeki değişkenlik havayolu işletmeleri üzerinde yoğun baskı oluşturmaktadır. Makro ve mikro çevrede meydana gelen gelişmeler, havacılık sektörünün büyümesine ve yeni markaların çoğalmasına kaynaklık etmektedir. Artık müşterilerin istek ve talepleri değişmekte, bilgi teknolojileri sayesinde ürün ve hizmetlere ulaşabilme imkanı da artmaktadır. Bu gelişmeler çerçevesinde müşteriyi elde tutmak, müşterinin istek ve taleplerine cevap verebilmek her geçen gün daha da zorlaşmaktadır.

Havayolu taşımacılığı hızlı, emniyetli, güvenilir ve esnek bir taşıma türü olmasının yanısıra diğer taşıma türlerine göre sigorta primleri daha düşüktür. Coğrafi alanı geniş, yerleşim alanları dağınık doğal koşulları ulaşım açısından çok elverişli olmayan bölgelerde havayolu taşımacılığı daha uygun niteliktedir. Buna karşın; kapıdan kapıya teslimatın yapılamaması, yakıt tüketiminin, sabit yatırım giderlerinin ve işletme maliyetlerinin yüksek olması sebebiyle dezavantaj oluşturmaktadır (Taşkın ve Durmaz, 2012:72). Kısa mesafelerde karayolu ve demiryolu taşımacılığı müşteriler tarafından daha fazla tercih edilmektedir (Keskin, 2015:268). Havayolu işletmelerinin amaçları arasında seyrüsefer güvenliğinin sağlanması, ülkenin milli stratejilerinin desteklenmesinin yanında kar maksimizasyonun sağlanması, çalışan ve müşteri memnuniyetinin artırılması da bulunmaktadır (Çalıyurt, 2012:18). Bu amaçların gerçekleşmesinde uçuş işletme, yer işletme, havayolu taşımacılık güvenliği, ekip planlama, satın alma, teknik bakım, kabin hizmetleri, eğitim, finans, muhasebe, halkla ilişkiler, kalite, insan kaynakları ve pazarlama bölümlerinin eşgüdüm içerisinde çalışmasına ihtiyaç vardır (Başol, 2012:71).

Müşterinin beklentisi istenilen zamanda, güvenli, rahat bir uçuşun gerçekleşmesi ve kaliteli bir hizmet almak ayrıca havayolu işletmesinin kendilerine değer katmasıdır. Globalleşmenin etkisiyle havayolu işletmelerinin hizmet kalitelerini müşteri odaklı olarak belirlemeleri, güçlü bir kurumsal imaja sahip olmaları ve sadık müşteri oluşmaya yönelik stratejiler geliştirmeleri önem arz etmektedir. Müşteri sadakati sağlamada müşteri memnuniyeti ve hizmet kalitesi anahtar bir rol oynamaktadır (Emir ve diğ. 2010:293). Günümüzde yalnızca ürün ve hizmet üretmek, müşteriye ilgi göstermek yeterli olmamaktadır. Diğer işletmelerden farklılaşması ve müşteriye değer kazandırması temel esastır ( Yıldırır, 2015: 343). İşletmenin tüketicinin gözünde iyi bir imajı oluşturmasının yanısıra hissedarlar, çalışanlar, yöneticiler ve işletme sahipleri nezninde de algılarının yüksek olması gerekmektedir (Skandrani ve diğ., (2011:53). Ürün ve hizmetlerin algilanan hizmet kalitesi uluslararası çevredeki kurumsal itibarı biçimlendirebilme özelliğine sahiptir. Bu nedenle; kurumsal imaj işletmelerin varlıklarını sürdürmesinde, marka değerlerini ve müşteri memnuniyetini artırmasında anahtar bir rol üstlenmektedir.

Çalışmamız beş bölümden oluşmaktadır. Birinci bölümde giriş, ikinci bölümde havayolu taşımacılığı, hizmet kalitesi, kurumsal imaj, müşteri memnuniyeti ve müşteri sadakati alanlarında literatür taraması yer almaktadır. Üçüncü bölümde çalışmanın yöntemi, amacı, modeli, ölçeklerin oluşturulması incelenirken, dördüncü bölümde güvenirlik analizi, faktör analizi, kolerasyon ve regresyon analizleri yapılmıştır. Beşinci bölümde çalışmaya ilişkin değerlendirmeler ve sonuçlar açıklanmıştır.

\section{KURAMSAL ÇERÇEVE}

\subsection{Havayolu Taşımacılığında Hizmet Kalitesi}

Hizmet müşteriye doyum ve yarar sağlayan ücret karşıllğında yada ücretsiz bir şekilde yapılan faaliyetler bütünü olarak tanımlanmaktadır. Hizmet, stoklanmayan ve üretici ile müşteri arasında yoğun bir iletişimin hakim olduğu sübjektif bir olgudur (Murdick ve diğ. 1990). Hizmet kalitesi ise müşterinin istek ve beklentilerini en iyi şekilde karşılanması olarak betimlenmektedir. Hizmet kalitesinin beklenen düzeyde yada beklenin üstünde olması halinde, müşterilerin ürün ve hizmetleri tekrardan satın almasına imkan sağlamakta, işletmenin karlılığın ve pazar payının artmasına kaynaklık etmektedir (Gilberta ve Wong, 2003:519). Eğer hizmet kalitesi müşteri nezdinde beklenen düzeyin altında ise, müşteri sadakatinde büyük bir azalma 


\section{G. Yanginlar - F. Tuna 12/1 (2020) 173-187}

meydana gelmektedir. Yapılan araştırmalar sonucunda, müşterilerin büyük bir kısmının ürün kalitesindeki sorunları nedeniyle değil, hizmet kalitesindeki problemler sebebiyle tekrar satın almayı düşünmediklerini beyan etmişlerdir (Gowan ve diğ, 2001:277).

Hizmet kalitesi "ilgi, yeterlilik, güvenirlilik, somut özellikler ve heveslilik" başlıkları altında eğitim sektöründe ölçülmüştür. Yeterlilik ve heveslilik faktörlerinin diğer boyutlara göre daha fazla önemsendiği sonucuna varılmıştır (Yılmaz ve Filiz, 2007). Ay ve Uçar (2016) ise; eğitim sektöründe hizmet kalitesi algısının cinsiyet değişkenine göre farklılık gösterdiğini ve kadınların hizmet kalitesi algılarının daha yüksek olduğunu belirtmektedir. Gülseven ve diğ. (2012) çalışmalarında katılımcıların cinsiyetine ve eğitim düzeylerine göre hizmet kalitesi algılarının anlamlı bir farklılık göstermediği sonucuna ulaşılmıştır. Şen ve Akpur (2017) çalışmalarında havayolu taşımacılığında hizmet kalitesi algısının cinsiyete göre farklılık arz etmediği ama gelir durumu değişkenine göre güven alt boyutunda anlamlı bir farklılık oluşturduğu sonucuna ulaşmıştır.

Yapılan literatür taramasında, farklı taşıma modlarındaki hizmet kalitesinin etkilerinin incelendiği görülmektedir. Karadeniz ve Ünver (2014) çalışmasında denizyolu taşımacilığında hizmet kalitesini etkileyen en önemli faktörün "yeterlilik ve heveslilik" olduğu tespit edilmiştir. Denizyolu taşımacılığında hizmet kalitesi artığında müşteri memnuniyetinin de artış gösterdiği belirlenmiştir. Seçilmiş ve diğ. (2001) çalışmasında, demiryolu taşımacılığında hizmet kalitesini "doğruluk, zaman, bilgilendirme, konfor, servis hizmetleri" başlıkları altında ele almıştır. Doğruluk boyutunun ödenen ücret açısından tatmin edicilik düzeyini en fazla etkilediği belirlenmiştir. Prasad ve Shekdar (2010) çalı̧̧malarında, Hindistan demiryollarındaki hizmet kalitesi Servqual yönetimiyle analiz edilmiştir. Rahaman ve Rahaman (2009) çalışmalarında ise Bangladeş demiryolu taşımacılığında belirli rotalar seçilerek, demiryolu hizmet kalitesi ile müşteri tatmini arasındaki ilişki değerlendirilmiştir

Parasuraman ve dĭ̆. (1985) çalışmalarında, hizmet kalitesini empati, güven, fiziksel özellikler, güvenirlik ve sorumluluk başlıkları altında ele almışlardır. Havayolu taşımacılığında hizmet kalitesi fiziki görünüm, heveslilik, yeterlilik, duyarlılık, güvenirlik unsurlarına göre incelenmiştir (Karadeniz ve Demirkan (2015; Hatipoğlu ve Işık 2015).

- Fiziki Görünüm: Havayolu taşımacılık hizmetinin sunulması için gerekli ekipmanların, binaların mevcut olmasının yanısıra uçuş esnasında veya uçuş zamanına kadar vakit geçirebilecek farklı eğlence seçeneklerinin bulunmasını da kapsamaktadır. Fiziksel görünüm unsurları arasında uçakların iç ve dış görünümleri, çalışanların güler yüzlü ve yolcuların ihtiyaçlarının farkında olması da yer almaktadır.

- Güvenilirlilik: Havayolu taşımacılık hizmetinde vaat edilen unsurların doğru bir şekilde yerine getirilmesidir. Zamanında uçuş hizmetinin verilmesi, yolcu bagajlarının zamanında teslim edilmesi, ikram edilen yiyecek ve içeceklerin kaliteli olması ve havayolu personelin yolcuları doğru bilgilendirmesi şeklinde örneklendirilebilir.

- Heveslilik: Havayolu taşımacılık hizmetin sunulmasında işletmenin ve çalışanların istekli ve gönüllü olması durumudur. Hizmet kalitesi açısından havayolu çalışanlarının hizmetlerin ne zaman gerçekleşeceği hususunda yolcuyu bilgilendirmesi, çalışanların zamanında ve hızlı havayolu hizmeti sunmaları ve yolcuya yardımcı olmaya çalışmaları önemli etkenlerdir.

- Güven: Havayolu şirketinde uçuşların ertelenme ve iptal edilme olasıllğı müşteri nezdinde önem arz etmektedir. Havayolu çalışanlarının teknik bilgisi ve davranışlarının yolculara güven vermesi, algılanan hizmet kalitesini olumlu yönde etkilemektedir.

- Empati: Havayolu işletmesinin müşteri istek ve talepleri doğrultusunda uçuş tarifelerini, fiyat çizelgesini düzenlemesi, havacılık hizmetinin her aşamasında (seyrüsefer esnasında, uçuş öncesi ve sonrasında) her müşteriye özel ilgi göstermesi empati ilkesi çerçevesinde incelenmektedir.

Havayolu taşımacilığında hizmet kalitesi, havayolu işletmesi ile tüketici etkileşimi sonucu ortaya çıan ve kurumsal imajı doğrudan etkileyen bir olgudur (Gürsoy ve diğ. 2005). Havayolu taşımacılığında liberalleşme süreci öncesinde hizmet kalitesi, transit zamanlar, uçak tipleri, yükleme- boşaltma performansı, uçuş sıklığ 1 gibi bazı değişkenlere bağlı iken, liberalleşme sonrası artan rekabet ortamında müşteri odaklı yaklaşım ön plana çıkmış ve hizmet kalitesi kavramının önemi daha da artmıştır (Tiernan ve diğ. 2008:2). Havayolu taşımacılığında hizmet kalitesi, uçuş öncesi, seyrüsefer esnası ve uçuş sonrası olarak ele alınmaktadır. Havayolu işletmesinin uçuş öncesi rezervasyon, bilet satışı, check in, bagaj kabulü, boarding, pasaport\& vize 


\section{G. Yanginlar - F. Tuna 12/1 (2020) 173-187}

kontrol aşamalarında sunmuş olduğu hizmetin yanısıra, uçuş sonrasında da bagaj teslimi, istek \& taleplerin değerlendirilmesi süreçlerindeki etkinliği kalite algısını yönlendirmektedir. Uçuş esnasındaki servis kalitesi, güvenlik ve konfor ön planda yer alan unsurlardır.

Havayolu taşımacılığında hizmet kalitesi literatürde birçok çalışmada ele alınmıştır. Hatipoğlu ve Işık (2015) çalışmalarında, havayolu taşımacılığında hizmet kalitesi "fiziki görünüm, güvenirlik, isteklilik, teminat, empati" faktörlerine göre sınıflandırılmış ve Servqual yöntemi ile analiz edilmiştir. Müşterinin algıladığı hizmet kalitesi ile havayolu taşımacılığını kullanma sıklığı arasında negatif yönlü bir ilişki olduğuna dikkat çekilmektedir. Chang ve Yeh (2002), Tayvan'daki iç hat yolcularının hizmet kalitesini " konfor, personel, güvenirlik, uygunluk" kriterleri çerçevesinde bulanık çoklu kriter modeli ile değerlendirmiştir. Kazançoğlu ve Kazançoğlu (2013) çalışmalarında, havayolu yolcu taşımacılığının hizmet kalitesini ölçmek amacıyla bulanık mantık tabanlı çok kriterli bir karar verme tekniği kullanılmıştır. İç hat yolcuları tarafından havayolu işletmelerinin hizmet kalitesi değerlendirilmiş ve bu işletmeler karşılaştırılmıştır. Okumuş ve Asil (2007) çalışmalarında ise, havayolu taşımacılığında müşteri memnuniyetini artırmada en önemli hizmet kalitesi boyutunun hizmet olduğu, daha sonra güvenilir hizmet, müşteriyi tanıma ve güven faktörlerinin etkili olduğu tespit edilmiştir. Görkem ve Yağcı (2016) çalışmalarında Thy'deki kabin içi hizmet kalitesi unsurlarından catering hizmetinin müşteri memnuniyeti sağlamada en etkili kriter olduğunu daha sonra koltuk rahatllğının, personel hizmetlerinin ve kabin içi eğlence imkanlarının takip ettiğine değinmektedirler. Ayrıca, Asya- Pasifik orijinli yolcularda kabiniçi hizmet kalitesi algısının diğer yolculara göre daha düşük olduğu belirlenmiştir. Ataman ve diğ. (2011), Türkiye'deki havayolu taşımacılığının hizmet kalitesinin ölçümünde en yüksek değerin güvenirlik olduğu sonucuna ulaşılmıştır. Havayolu taşımacılık hizmetinin eksiksiz bir şekilde yerine getirilmesinin ve verilen taahhütlere bağlı kalınarak sürecin gerçekleştirilmesinin altı çizilmektedir.

Havayolu taşımacılığında teknolojik entegrasyonun sağlanması ve çevreye duyarlılığın tüketici talepleri ve yasal düzenlemeler ile artması, havayolu taşımacilığının çevreye verdiği zararların azalmasına imkan sağlamaktadır. Havayolu taşımacılığında istihdam edilen personelin eğitimine gerekli yatırımların yapılması ve sıfır hata ile bütün süreçlerin organize edilmesini hedeflenmesi hizmet kalitesinin artmasına kaynaklık etmektedir. Yolculardan havalimanlarının ve diğer tesislerin kullanılmasına ilişkin özel bir vergi alınmaması yolcu memnuniyetini artıran bir unsurdur (Karacan ve Kaya, 2011:26).Uçaklarda gelişmiş teknik sistemlerin kullanılması, modern, konforlu seyahat imkanının sunulması, tüketici memnuniyetini ve kurumsal imajı olumlu yönde etkilemektedir. (Koban ve Keser, 2011:216).

\subsection{Kurumsal İmaj}

Endüstri devriminden sonra rekabet avantajı elde etmenin yolları keşfedilirken kurumsal imaj kavramının ortaya çıktığı belirlenmiştir. İlk yıllarda işletmelere görsel bir kimlik kazandırarak kurumsal imaj oluşturmanın yeterli olduğu düşünülse de, 1990'dan sonra bu anlayışın değiştiği görülmektedir. Günümüzde kurumsal imaj sadece pazarlama ve tasarım uzmanlarının ilgilendiği bir bölümden, farklı disiplinlerinde odak noktası olan bir boyuta ulaşmıştır (Jacobson ve Abratt, 2003).

Kurumsal imaj, örgütün sahip olduğu maddi ve manevi unsurların kamuoyunun zihninde oluşan sanal resimi yada dış çevreden algılanışı olarak tanımlanmaktadır (Guo ve diğ. 2008:306). İşletmenin hedef kitlesinde yer alan tüketicilerin, işletmenin logosunu gördüklerinde yada ismini duyduklarında belleklerinde oluşan resim kurumsal imajı betimlemektedir (Gray, Balmer, 1998: 696). Bunun yanısıra; kurumsal imaj işletme hissedarlarının kurumla olan ilişkilerinde hissetikleri bağlllı̆̆ın derecesi yada farklı müşteri kitlelerin kurumsal çekicilik algıları olarak da ifade edilmektedir. (Arendt ve Brettel, 2010:1474). Rekabet avantajı yaratmak isteyen işletmeler nasıl bir kurumsal imaj oluşturmayı planlıyorlarsa, o imaja yönelik farkındalığa ulaşmaları temel esastır (Taslak ve Akın, 2005: 268).

Küreselleşmenin etkilerinin yoğun olarak hissedildiği bu zaman diliminde, işletmelerin amaç ve hedeflerine ulaşmasında ve müşteri memnuniyeti sağlamasında kurumsal imaj anahtar bir rol üstlenmektedir (Bolat, 2006:111). Tüketicilerin yeniden satın alma davranışı sergilemesinde, yatırım ve istihdam kararlarında kurumsal imaj etkili olmaktadır (Chattananon, 2008:349). Kurumsal imaj uluslararası pazarlarda daha kolay sermaye tedarik edilmesinde, nitelikli ve yetenekli işgörenlerin işletmeye çekilmesinde de avantaj sağlamaktadır (Taşlıyan ve diğ. 2013: 778).

Kurumsal imaj işletme ürün \& hizmet kalitesinin, saygınlığının ve çekiciliğinin artmasına kaynak eden bir olgudur. Bunun yanısıra çalışanların motivasyonu ve iş tatmini de (Özgözgü, 2016:583) olumlu yönde 


\section{G. Yanginlar - F. Tuna 12/1 (2020) 173-187}

etkilemektedir. Yavuz (2010) çalışmasında, kurumsal sosyal sorumluluk gösteren işletmelerin kurumsal imajlarının daha yüksek olduğunu kanıtlanmıştır. Çınaroğlu ve Şahin (2012) çalışmalarında sağlık sektöründeki kurumsal imaj ile işletme performans kriterlerinden hizmet kalitesi ve müşteri memnuniyeti arasında güçlü bir ilişkinin olduğunu belirtmektedir. Koçak (2014) çalışmasında ise, ürün\& hizmetlerin müşteriler tarafından tercih edilmesinde ve işletmenin pazar payını artırmasında kurumsal imajın önemi vurgulanmıştır. Canöz (2015) çalışmasında Türkiye'deki havayolu işletmelerinin imajları karşılaştırılmıştır. Thy, Atlasjet, Pegasus havayollarının "hizmet kalitesi, kurumsal reklamcılık, halkla ilişkiler, görsel kimlik, kurumsal iletişim ve sponsorluk" imaj bileşenlerine önem verdikleri tespit edilmiştir.

\subsection{Müşteri Memnuniyeti ve Müşteri Sadakati}

Memnuniyet, müşterinin beklediği yada arzu ettiği ürün veya hizmete verdiği bir yanit olarak ifade edilmektedir (Mohammad ve Alhamadani, 2011:63). Müşteri memnuniyet ise; ürün veya hizmetlerin müşteri istek ve beklentilerine uygun veya beklentisinin ötesine geçmesini kapsayan bir kavramdır (Andaleeb ve Conway, 2006:4; Özgüven 2008:657 ). Bu kavram, bir ürün yada hizmeti satın almadan önce başlayan ve satış sonrası hizmetleri de kapsayan bir süreç olup, bu süreçteki olayların ve müşterinin elde ettiği kazançların beklentilerini ne derecede karşıladığını göstermektedir (Zeithaml ve Bitner, 2003).

Müşteri memnuniyeti, sadece ürün veya hizmetin özelliklerinin müşteri talep ve beklentilerini karşılamasıyla değil, aynı zamanda müşteri nezdinde önem arz eden unsurlara ait beklentilerin karşılanmasıyla gerçekleşmektedir (Kotler ve Armstrong, 2009:38-39). Gelişen teknolojinin etkisiyle müşteriler deneyimleri sonucu memnun yada memnunsuzluk durumlarını geniş kitleler ile paylaşmaktadır (Kim ve diğ. 2009:12). Memnun olmayan müşteri şikayetlerini beyan etmeyi ve problemlerinin en kısa zamanda çözümlenmesini bekleyedebilir veya sessiz sedasız işletmeyi terk ederek, tekrardan satın alma davranışı sergilememeyi de seçebilir (Hussain ve diğg. 2014:167). İşletmenin sessiz sedasız ayrılan ve memnuniyetsizliği yazılı veya sözlü olarak belirtmeyen müşteri kitlesini farkına varması zordur. Bu durum müşteri kayıp oranlarının artmasına kaynaklık etmektedir. İşletme açısından ele aldığımızda, yeni müşterileri portföye katmanın maliyeti ile eski müşterileri elde tutmaya çalışmanın maliyeti karşılaştırdığında eski müşterileri elde tutmaya çalışmanın daha düşük maliyetli olduğu tespit edilmiştir (Lin ve Wang, 2006:272). Sadık müşteriler, işletmenin hizmet kalitesinin daha üst seviyelere ulaşması için tavsiyelerde bulunmaktalar ve bir sorun ile karşılaştıklarında gerekli mercilere sorunu ilettikleri görülmektedir (Bove ve diğ. 2009:699). Sadık müşteri oranındaki çok ufak artışlar bile, işletme karını yüksek oranda etkileyebilecek niteliktedir (Tsaur ve diğg. 2002). Günümüzde memnun müşteri zaman içinde sadık müşteriye dönüşmekte ve bu müşteri portföyü işletmenin karını maksimize edebilme olanağı sunmaktadır (Yeung ve Ennew, 200:313-314).

Müşteri sadakati, tüketici satın alma kararlarını etkileyen ve ürün \& hizmete duyulan derin bağlılığı ifade eden bir olgudur (Kim ve diğ. 2007). Bu kavram, işletmenin nakit akışını etkileyen ve geleceğini garanti almasına imkan sağlayan bir süreçtir (Yurdakul, 2007:274). Müşteri sadakati müşterilerin ürün ve hizmetleri hiçbir karşılık gözetmeksizin diğer tüketiciler tavsiye etmesine (Çatı ve Koçoğlu, 2008) ve belirli ürün \& hizmetleri tekrar talep etmesine kaynaklık etmektedir (Lee ve diğ. 2001).

Yıldız ve Tehci (2014) çalışmasında, müşteri sadakati yaratmada en önemli unsurun fiyat olduğuna ve ürün yada hizmeti müşterilere sunan personelin özelliklerinin müşteri sadakatinde anlamlı bir etkisi olmadığına değinmektedir. Literatürde müşteri memnuniyeti ve müşteri sadakatine ilişkin birçok çalışma farklı sektörlerde ele alınmıştır. Turizm sektöründeki hizmet kalitesinin müşteri memnuniyetini doğrudan etkilediği ve müşteri memnuniyetindeki küçük artışların müşteri sadakatinde büyük değişimleri beraberinde getirdiği vurgulanmaktadır (Özer ve Günaydın, 2010:135). Otomotiv sektöründe ise, müşteri memnuniyeti yaratmada ve müşteri sadakati oluşturmada kurumsal marka kişiliğinin önemine dikkat çekilmektedir (Çobanoğlu ve Baykal, 2013:69). Otomotiv sektöründe müşteri memnuniyetinin işletme performansı üzerinde pozitif bir etkisi olduğu tespit edilmiştir (Küçükoğlu Tepe ve Pınar, 2015). Sağlık sektöründe müşterilerin ürün ve hizmet değiştirme maliyetinin yüksek olmasının, müşteri memnuiyeti ile müşteri sadakatinin arasındaki ilişkinin zayıf olmasına neden olduğu belirtilmektedir (Pişgin ve Ateşoğlu, 2015). Gıda sektöründe müşterinin markaya duyduğu güvenin müşteri sadakatini artırdığı ve marka ile müşteri arasındaki ilişkiyi güçlendirdiği sonucuna ulaşılmıştır (Kalyoncuoğlu, 2017:389). Yapılan literatür taramasında turizm, gıda, otomotiv ve sağlık sektörlerinde hizmet kalitesi, müşteri memnuniyeti, müşteri sadakati arasındaki ilişkiyi inceleyen birçok çalışmaya rastlanılmıştır. 


\section{ARAŞTIRMANIN YÖNTEMI}

\subsection{Araştırmanın Amacı ve Kapsamı}

Bu araştırmada havayolu taşımacılık hizmet kalitesinin kurum imaj, müşteri memnuniyeti ve müşteri sadakati üzerindeki etkisinin belirlemesi amaçlanmıştır. Araştırmanın evrenini, uluslararası tanınırlığa sahip bir havayolu işletmesinin Atatürk havalimanındaki dış hat yolcuları oluşturmaktadır. Örneklem büyüklüğü 800 olarak belirlenmiştir. Bu evren büyüklüğü için $\% 95$ güven düzeyi ve $\% 5$ tolerans düzeyinde örneklem büyüklüğünün 260 olması yeterli bulunmaktadır (Balc1, 2007:95). Araştırmada 260 anket formundan elde edilen verilerin değerlendirilmesinde Statistical Package for the Social Sciences (SPSS) paket programından yararlanılmıştır.

\subsection{Araştırmanın Modeli}

Çalışmanın amacı doğrultusunda araştırmanın modeli ve hipotezleri aşağıdaki gibi oluşturulmuştur.

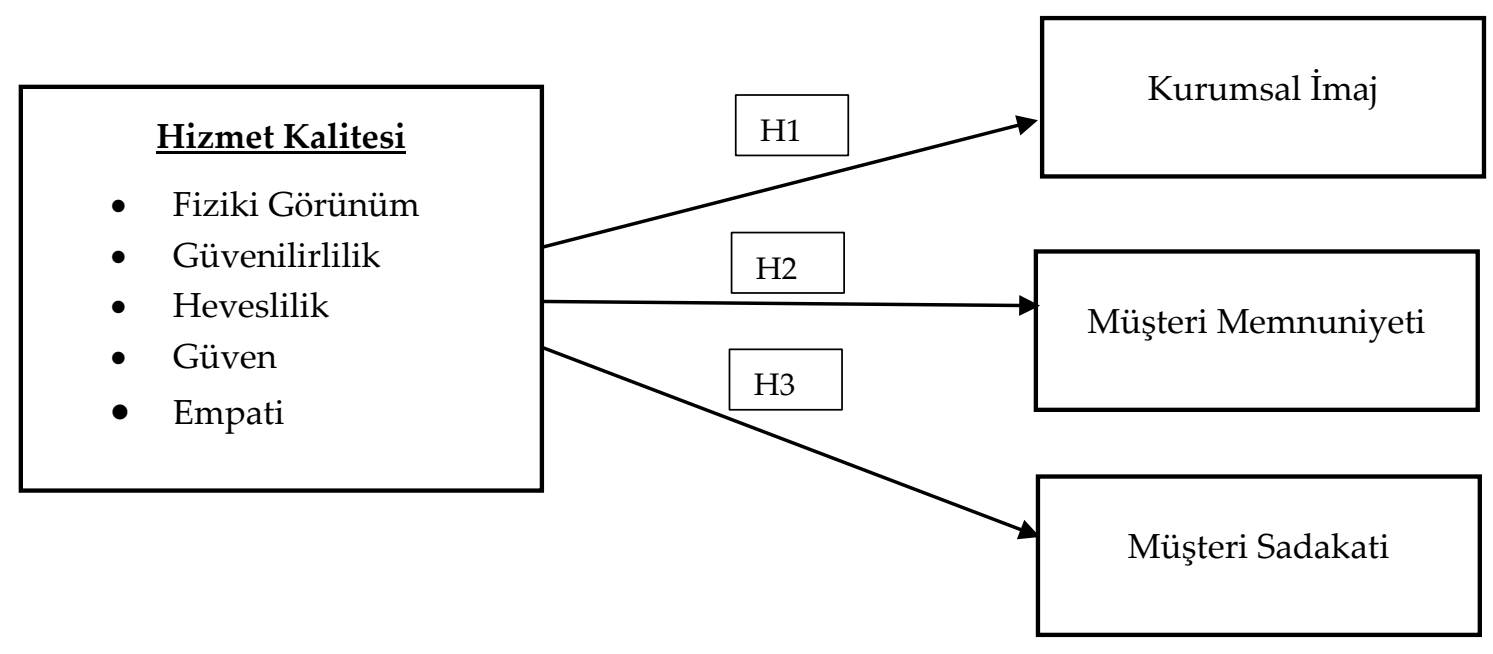

Şekil 1: Araştırmanın Modeli

\section{$\underline{\text { Hipotezler }}$}

$\mathrm{H}_{1}$ : Hizmet kalitesi ile kurumsal imaj arasında pozitif yönlü bir ilişki vardır.

Hıa: Hizmet kalitesi boyutlarından fiziki görünüm ile kurumsal imaj arasında pozitif yönlü bir ilişki vardır.

$\mathrm{H}_{1 b}$ : Hizmet kalitesi boyutlarından güvenilirlik ile kurumsal imaj arasında pozitif yönlü bir ilişki vardır.

H1c: Hizmet kalitesi boyutlarından heveslilik ile kurumsal imaj arasında pozitif yönlü bir ilişki vardır.

Hıd: Hizmet kalitesi boyutlarından güven ile kurumsal imaj arasında pozitif yönlü bir ilişki vardır.

Hı: Hizmet kalitesi boyutlarından empati ile kurumsal imaj arasında pozitif yönlü bir ilişki vardır.

$\mathrm{H}_{2}$ : Hizmet kalitesi ile müşteri memnuniyeti arasında pozitif yönlü bir ilişki vardır.

$\mathrm{H}_{2 a}$ : Hizmet kalitesi boyutlarından fiziki görünüm ile müşteri memnuniyeti arasında pozitif yönlü bir ilişki vardir.

$\mathrm{H}_{2 b}$ : Hizmet kalitesi boyutlarından güvenilirlik ile müşteri memnuniyeti arasında pozitif yönlü bir ilişki vardır.

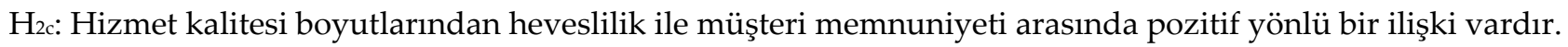

H2d: Hizmet kalitesi boyutlarından güven ile müşteri memnuniyeti arasında pozitif yönlü bir ilişki vardır.

H2e: Hizmet kalitesi boyutlarından empati ile müşteri memnuniyeti arasında pozitif yönlü bir ilişki vardır.

H3: Hizmet kalitesi ile müşteri sadakati arasında pozitif yönlü bir ilişki vardır.

Hза: Hizmet kalitesi boyutlarından fiziki görünüm ile müşteri sadakati arasında pozitif yönlü bir ilişki vardır. 


\section{G. Yanginlar - F. Tuna 12/1 (2020) 173-187}

Hзb: Hizmet kalitesi boyutlarından güvenilirlik ile müşteri sadakati arasında pozitif yönlü bir ilişki vardır.

H3c: Hizmet kalitesi boyutlarından heveslilik ile müşteri sadakati arasında pozitif yönlü bir ilişki vardır.

Hзs: Hizmet kalitesi boyutlarından güven ile müşteri sadakati arasında pozitif yönlü bir ilişki vardır.

Hзe: Hizmet kalitesi boyutlarından empati ile müşteri sadakati arasında pozitif yönlü bir ilişki vardır.

\subsection{Veri Toplama Araç ve Teknikleri}

Araştırmada uygulanan anketin geçerli ve araştırmanın amacına uygun olduğunu anlamak test etmek amacıyla, anketlerin güvenilirliği Cronbach Alfa Katsayısı kullanılarak hesaplanmıştır. Araştırmada kullanılan hizmet kalitesi ölçeği Karadeniz ve Demirkan (2015) ve Hatipoğlu ve Işık (2015) tarafından gerçekleştirilmiş olan çalışmadan uyarlanmıştır. Kurumsal imaj ölçeği Duygun ve Menteş (2016) tarafından gerçekleştirilmiş olan çalışmadan uyarlanmıştır. Müşteri memnuniyeti ölçeği Serçek ve Serçek (2016) tarafından gerçekleştirilmiş olan çalışmadan uyarlanmıştır. Müşteri sadakati ölçeği Çobanoğlu ve Baykal (2013) tarafından gerçekleştirilmiş olan çalışmadan uyarlanmıştır.

Anket formu iki temel bölümden oluşmaktadır. Birinci bölümde araştırmaya katılanların demografik özelliklerini belirlemeye yönelik 7 soru yer almaktadır. İkinci bölümde ise hizmet kalitesi, kurumsal imaj, müşteri memnuniyeti ve müşteri sadakatini içeren soru grupları yer almaktadır. Hizmet kalitesi ölçeği toplamda 5 alt faktöre ayrılmıştır. Bunlar fiziki görünüm, güvenilirlik, heveslilik, güven ve empatidir. Hizmet kalitesi ölçeği toplamda 22 ifadeden meydana gelmektedir. Ancak çalışma kapsamında faktör analizlerinin yapılmasının ardından hizmet kalitesi ölçeği 17 soruya indirgenmiştir.

Anket soruları; katılımcıların memnuniyet yargılarına katılım derecesini ölçmek amacıyla 5'li likert $(1=$ kesinlikle katılmıyorum, 2 = katılmıyorum, 3 =Kararsızım, 4 = katılıyorum, 5 = kesinlikle katılıyorum) ölçeğinde hazırlanmış olup katılımcılardan en uygun olan seçeneği işaretlemeleri istenmiştir.

\subsection{Araştırmanın Sınırlılıkları}

Bu çalışma zaman ve maliyet kısıtından dolayı yalnızca İstanbul ilinde ve Atatürk Havalimanı dış hatlar terminalinde yapılmıştır. Yolculardan bazılarının anket yapmaya vakitlerinin olmadığını beyan ederek uygulamayı reddetmesi ve saha çalışmasına izin verilen tarihlerin kısıtlı olması diğer bir kısıtları oluşturmaktadır.

\section{BULGULAR VE YORUMLAR}

\subsection{Geçerlilik Bulguları}

Tablo 1. Hizmet Kalitesi Ölçeği Faktör Analizi

\begin{tabular}{|c|c|c|c|}
\hline Sorular & Ort. & $\begin{array}{l}\text { Faktör } \\
\text { Yükleri }\end{array}$ & $\begin{array}{c}\text { Varyans } \\
(\%)\end{array}$ \\
\hline \multicolumn{4}{|l|}{ Fiziki Görünüm } \\
\hline $\begin{array}{l}\text { Havayolu işletmesinin hizmetleri gerçekleştirirken kullandıkları } \\
\text { ekipman ve malzemelerin çeşitliliği yeterlidir. }\end{array}$ & & 0.842 & \\
\hline Havayolu işletmesinin uçaklarının içi ve dış görünümü etkileyicidir. & & 0,823 & \\
\hline $\begin{array}{l}\text { Havayolu işletmesinin uçuşu sırasında veya uçuş zamanına kadar vakit } \\
\text { geçirmek için farklı eğlence seçenekleri mevcuttur. }\end{array}$ & 3,921 & 0,772 & 63,906 \\
\hline $\begin{array}{l}\text { Havayolu işletmesinin uçuşu sırasında ikram edilen yiyecek ve } \\
\text { içecekler kalitelidir. }\end{array}$ & & 0,757 & \\
\hline
\end{tabular}

\section{Güvenilirlilik}

Havayolu işletmesinin uçuş hizmetinin her aşamasında yolcularını doğru bilgilendirir.

Havayolu işletmesi yolcularının bagajları zamanında ve eksiksiz teslim edilir.

Havayolu işletmesi uçuş tarifelerine uygun olarak kalkış ve varış saatleri tam zamanında gerçekleşir.

\footnotetext{
Heveslilik

Havayolu işletmesinin çalışanlarını hizmetin ne zaman gerçekleşeceği konusunda yolcuya bilgi verir.
} 
Havayolu işletmesinin çalışanları zamanında ve hızlı hizmet verir.

\section{Güven}

Havayolu işletmesinin çalışanları yolculara karşı saygılı davranır.

0,814

Havayolu işletmesinin çalışanlarının teknik bilgisi ve davranışları yolculara güven duygusu verir.

Havayolu işletmesinde uçuşların iptal edilme ve ertelenme olasılı̆̆ının düşüktür.

\section{Empati}

Havayolu işletmesinin çalışanları uçuş öncesinde, sırasında ve sonrasında sunmuş oldukları hizmette her müşteriye özel ilgi gösterir.

\section{0,867}

Havayolu işletmesinin yolcuların en ekonomik fiyat tarifesi ile uçmaları için gerekli düzenlemeleri yapar

Havayolu işletmesinin uçuş tarifelerini yolcuların taleplerine uygun düzenlenir.

Havayolu işletmesinin müşteri hizmetleri departmanı yolcuların dilek ve şikayetlerine cevap verebilmek için çaba sarf eder.
0,820

0,800

\section{0,855}

3,546

69,859

Faktör analizine göre hizmet kalitesi ölçeği 17 maddeli beş boyutlu bir yapı teşkil etmektedir. Hizmet kalitesi ölçeği; fiziki görünüm, güvenirlilik, heveslilik, güven ve yeterlilik olarak alt faktörlere ayrılmıştır. Kurumsal imaj ölçeğinin faktör yükü 0,787 , müşteri memnuniyetinin faktör yükü 0,856 , müşteri sadakatinin faktör yükü 0,851 olarak belirlenmiştir.

\subsection{Güvenilirlik Bulguları}

Saha araştırmasında kullanılan anket literatürde yer alan ölçeklerden faydalanılarak oluşturulmuştur. Kullanılan ölçeklerin güvenirliğini incelemek amacıyla Cronbach's Alpha analizi uygulanmıştır. Gerçekleştirilmiş olan tüm anket soruları ile yapılan güvenilirlik analizi sonucuna göre güvenilirlik katsayısı $\alpha=0,952$ olarak belirlenmiş ve ölçeğin oldukça güvenilir olduğu tespit edilmiştir.

Tablo 2. Güvenilirlik Analizi

\begin{tabular}{cc}
\hline & Cronbach's Alpha \\
\hline Hizmet Kalitesi Ölçeği & 0,890 \\
Fiziki Görünüm & 0,806 \\
Güvenilirlilik & 0,719 \\
Heveslilik & 0,622 \\
Güven & 0,692 \\
Empati & 0,855 \\
Kurumsal İmaj Ölçeği & 0,830 \\
Müssteri Memnuniyeti Ölçeği & 0,888 \\
Müşteri Sadakati Ölçeği & 0,890 \\
\hline
\end{tabular}

Hizmet kalitesi ölçeği 17 sorudan oluşmaktadır, Güvenilirlik katsayısı; $\alpha=0,890$ olarak bulunmuştur. Ayrıca hizmet kalitesi ölçeğinin alt ölçekleri ile yapılan güvenilirlik analizi sonuçları da sırası ile fiziki görünüm $\alpha=$ 0,806 , güvenilirlilik $\alpha=0,719$, heveslilik $\alpha=0,622$, güven $\alpha=0,692$ ve son olarak empati $\alpha=0,855$ olarak bulunmuştur. Kurumsal imaj soruları 7 sorudan oluşmaktadır, güvenilirlik katsayısı $\alpha=0,830$ olarak ölçülmüştür. Diğer, iki faktör olan müşteri memnuniyeti ölçeği 8 sorudan ve müşteri sadakati ölçeği 5 sorudan oluşmaktadır. Güvenilirlik katsayıları ise bu iki ölçeğin sırasıyla, $\alpha=0,888$ ve $\alpha=0,890$ olarak ölçülmüştür.

\subsection{Demografik Bulgular}

Bu başlık altında araştırmada elde edilen demografik bulgulara yer verilmiştir. 
Tablo 3. Demografik Bulgular

\begin{tabular}{|c|c|c|}
\hline Yaş Dağılımı & Frekans & $\%$ \\
\hline $18-25$ & 52 & 20,0 \\
\hline $26-35$ & 144 & 55,4 \\
\hline $36-45$ & 48 & 18,5 \\
\hline $46-55$ & 14 & 5,4 \\
\hline $55+$ & 2 & 0,7 \\
\hline Toplam & 260 & 100 \\
\hline Cinsiyet Dağılımı & Frekans & $\%$ \\
\hline Erkek & 188 & 27,7 \\
\hline Kadın & 72 & 72,3 \\
\hline $\begin{array}{l}\text { Toplam } \\
\end{array}$ & 260 & 100 \\
\hline Eğitim Durumu Dağılımı & Frekans & $\%$ \\
\hline Lise & 34 & 13,1 \\
\hline Lisans & 138 & 53,1 \\
\hline Lisansüstü & 86 & 33,1 \\
\hline Diğer & 2 & 0,7 \\
\hline Toplam & 260 & 100 \\
\hline Meslek Dağılımı & Frekans & $\%$ \\
\hline Öğrenci & 28 & 10,8 \\
\hline İşçi & 42 & 16,2 \\
\hline Memur & 156 & 60,0 \\
\hline Serbest Meslek & 34 & 13,0 \\
\hline Toplam & 260 & 100 \\
\hline Uçuş Sıklığ1 Dağılımı & Frekans & $\%$ \\
\hline Yilda $1 \mathrm{Kez}$ & 108 & 41,5 \\
\hline 6 Ayda $1 \mathrm{Kez}$ & 42 & 16,2 \\
\hline Yilda 4-5 Kez & 78 & 30,0 \\
\hline Ayda 1 & 14 & 5,4 \\
\hline Ayda 1'den Fazla & 18 & 6,9 \\
\hline Toplam & 260 & 100 \\
\hline Uçuş Amacı Dağılımı & Frekans & $\%$ \\
\hline Turistik & 134 & 51.6 \\
\hline Mesleki & 96 & 36.9 \\
\hline Ticaret & 18 & 6.9 \\
\hline Ailevi & 12 & 4.6 \\
\hline Toplam & 260 & 100 \\
\hline Gelir Düzeyi Dağılımı & Frekans & $\%$ \\
\hline 2500 TL'ye kadar & 52 & 20.0 \\
\hline 2501-3000 TL & 30 & 11.5 \\
\hline $3501-4500 \mathrm{TL}$ & 84 & 32.3 \\
\hline $4501-5500 \mathrm{TL}$ & 42 & 16.2 \\
\hline 5501-6500 TL & 36 & 13.8 \\
\hline 6.500 ve üzeri TL & 16 & 6.2 \\
\hline Toplam & 260 & 100 \\
\hline
\end{tabular}

Tablo 3'e göre, katılımcıların \%55,4'lük kısmının 26-35 yaş aralığında olduğu belirlenmiştir. Katılımcıların cinsiyet gruplarına bakıldığında \%72,3'lük kısmı erkeklerin, \%27,3'lük kısmı ise kadınların oluşturduğu görülmektedir. Dolayısıyla, örneklemin önemli bir bölümü erkeklerden oluşmaktadır.

Katılımcıların büyük bir çoğunluğunun lisans mezunu $(\% 53,1)$ olduğu belirlenmiştir. Eğitim düzeylerinin yüksek olduğu saptanmıştır. Mesleki dağılıma göre, ankete katılanların büyük bir çoğunluğunun (\%60) memur olduğu görülmektedir. Yurtdışı uçuş sayısına ilişkin soruda en az uçuş sıklığına sahip kişiler \%41,5'lik kısmı ile yılda $1 \mathrm{kez}$ ve uçuş sıklığı ez fazla olan kişiler ise \%5,4'lük kısmı ile ayda 1 'den fazla uçtuğu 
görülmektedir. Katılımcıların \%57,7'unun 6 ay ile 1 yıl arası 1 kez yurtdışı uçuş tecrübesi edindikleri tespit edilmiştir. Araştırmaya katılanların \%51,6'lık kısmının turistik, \%36,9'luk kısmının mesleki, \%6,9'luk kısmının ticaret, \%4,6'lık kısmı ailevi sebeplerden dolayı yurtdışı seyahati gerçekleştirdikleri belirlenmiştir. Gelir seviyesi açısından katılımcıların \%32.3'nün gelirinin 3501-4500 TL olduğu saptanmıştır. Katılımcıların demografik özelliklerinin farklı olması örneklemin temsil yeteneğini güçlendirmektedir.

\subsection{Araştırmanın Hipotez Testleri Bulguları}

Havayolu taşımacılığında hizmet kalitesi alt faktörleri ile kurumsal imaj, müşteri memnuniyeti ve müşteri sadakati arasında ilişki olup olmadığını belirlemek amacıyla korelasyon analizi yapılmıştır. Elde edilen bulgular Tablo 4'de sunulmuştur. Daha sonra, hizmet kalitesi ölçeği ile kurumsal imaj, müşteri memnuniyeti ve müşteri sadakati ölçekleri arasında ayrı ayrı regresyon analizine yer verilmiştir.

Tablo 4. Değişkenlere Arasındaki Kolerasyon Analizi

\begin{tabular}{|c|c|c|c|c|c|c|c|c|}
\hline & F.G & G.L & $\mathbf{H}$ & G & E & K.İ & M.M & M.S \\
\hline Fiziki Görünüm (F.G) & 1 & & & & & & & \\
\hline Güvenilirlilik (G.L) & $0,341^{* *}$ & 1 & & & & & & \\
\hline Heveslilik (H) & $0,552^{* *}$ & $0,418^{* *}$ & 1 & & & & & \\
\hline Güven (G) & $0,425^{* *}$ & $0,505^{* *}$ & $0,704^{* *}$ & 1 & & & & \\
\hline Empati (E) & $0,555^{* *}$ & $0,199^{* *}$ & $0,630^{* *}$ & $0,325^{* *}$ & 1 & & & \\
\hline Kurumsal İmaj (K.İ) & $0,467^{* *}$ & $0,377^{* *}$ & $0,548^{* *}$ & $0,554^{* *}$ & $0,491^{* *}$ & $1^{* *}$ & & \\
\hline Müşteri Memnuniyeti (M.M & $0,550^{* *}$ & $0,382^{* *}$ & $0,594^{* *}$ & $0,464^{* *}$ & $0,657^{* *}$ & $0,596^{* *}$ & $1^{* *}$ & \\
\hline Müşteri Sadakati (M.S) & $0,463^{* *}$ & $0,303^{* *}$ & $0,413^{* *}$ & $0,353^{* *}$ & $0,483^{* *}$ & $0,484^{* *}$ & $0,718^{* *}$ & $1^{* *}$ \\
\hline
\end{tabular}

**\%1 önem seviyesinde anlamlıdır.

Hizmet kalitesinin alt boyutlarını oluşturan fiziki görünüm, güvenilirlilik, güven, empati ve heveslilik ile kurumsal imaj, müşteri memnuniyeti, müşteri sadakati arasında pozitif yönlü bir ilişki olduğu belirlenmiştir.

Tablo 5. Hizmet Kalitesi Ölçeği ile Kurumsal İmaj Arasında Regresyon Analiz Tablosu

\begin{tabular}{|c|c|c|c|c|c|c|}
\hline \multirow[t]{2}{*}{ Model } & \multirow[t]{2}{*}{$\mathbf{R}$} & \multirow[t]{2}{*}{$\mathbf{R}^{2}$} & \multicolumn{2}{|l|}{ Düzeltilmiş $\mathbf{R}^{2}$} & \multicolumn{2}{|c|}{ Standart Tahmini Hata } \\
\hline & & & & $\mathbf{F}$ & & \\
\hline 1 & $0,659 a$ & 0,434 & 0,423 & 38,944 & \multicolumn{2}{|c|}{0,46854} \\
\hline \multirow{3}{*}{\multicolumn{2}{|c|}{ Model }} & & K1 & SK2 & $t$ & $\mathrm{p}$ \\
\hline & & B & Std. Hata & Beta & & \\
\hline & & 1,514 & 0,208 & & 7,291 & 0,000 \\
\hline \multicolumn{2}{|c|}{ Fiziki Görünüm } & 0,086 & 0,044 & 0,119 & 1,952 & 0,052 \\
\hline \multicolumn{2}{|c|}{ Güvenilirlilik } & 0,082 & 0,048 & 0,095 & 1,703 & 0,090 \\
\hline \multicolumn{2}{|c|}{ Heveslilik } & 0,018 & 0,077 & 0,019 & 0,232 & 0,817 \\
\hline \multicolumn{2}{|l|}{ Güven } & 0,308 & 0,063 & 0,351 & 4,880 & 0,000 \\
\hline \multicolumn{2}{|l|}{ Empati } & 0,184 & 0,044 & 0,279 & 4,203 & 0,000 \\
\hline
\end{tabular}

SK1: Standartlaştırılmamış Katsayılar, SK2: Standartlaştırılmış Katsayılar

Tablo 5' de yer alan sonuçlar incelendiğinde kurulan regresyon modelinin 0,001 anlamlılık düzeyinde geçerli olduğu görülmektedir ( $\mathrm{F}$ değeri $=38,944)$. Güven ve empati faktörlerinin kurumsal imajı pozitif yönde etkilediği saptanmıştır. Bu bilgiler ışı̆̆ında; H1d, H1e hipotezlerinin desteklendiği, H1a, H1b, H1c hipotezlerinin ise desteklenmediği sonucuna ulaşılmıştır. 
G. Yanginlar - F. Tuna 12/1 (2020) 173-187

Tablo 6. Hizmet Kalitesi Ölçeği ile Müşteri Memnuniyeti Arasında Regresyon Analiz Tablosu

\begin{tabular}{|c|c|c|c|c|c|c|}
\hline \multirow[t]{2}{*}{ Model } & \multirow[t]{2}{*}{$\mathbf{R}$} & \multirow[t]{2}{*}{$\mathbf{R}^{2}$} & \multirow[t]{2}{*}{ Düzeltilmiş $\mathbf{R}^{2}$} & \multicolumn{3}{|c|}{ Standart Tahmini Hata } \\
\hline & & & & $\mathbf{F}$ & & \\
\hline \multirow[t]{3}{*}{1} & $0,735^{\mathrm{a}}$ & 0,541 & 0,532 & 59,824 & \multicolumn{2}{|c|}{0,50851} \\
\hline & \multirow[t]{2}{*}{ Model } & & & SK2 & $t$ & p \\
\hline & & B & Std. Error & Beta & & \\
\hline \multirow[t]{6}{*}{1} & & 0,471 & 0,225 & & 2,091 & 0,038 \\
\hline & Fiziki Görünüm & 0,134 & 0,048 & 0,154 & 2,802 & 0,005 \\
\hline & Güvenilirlilik & 0,150 & 0,052 & 0,144 & 2,877 & 0,004 \\
\hline & Heveslilik & 0,079 & 0,083 & 0,072 & 0,949 & 0,344 \\
\hline & Güven & 0,134 & 0,069 & 0,127 & 1,952 & 0,052 \\
\hline & Empati & 0,363 & 0,048 & 0,456 & 7,623 & 0,000 \\
\hline
\end{tabular}

SK1: Standartlaştırılmamış Katsayılar, SK2: Standartlaştııılmış Katsayılar

Tablo 6'daki çoklu doğrusal regresyon analizi sonuçları incelendiğinde, hizmet kalitesi alt değişkenlerinden fiziki görünüm, güvenilirlik ve empatinin müşteri memnuniyetini pozitif yönde etkilediği belirlenmiştir. Bu bilgiler ışığında; H2a, H2b ve H2e hipotezlerinin desteklendiği, $\mathrm{H} 2 \mathrm{c}$ ve H2d hipotezinin ise desteklenmediği sonucuna ulaşılmıştır.

Tablo 7. Hizmet Kalitesi Ölçeği ile Müşteri Sadakati Arasında Regresyon Analiz Tablosu

\begin{tabular}{ccccccc}
\hline Model & $\mathbf{R}$ & $\mathbf{R}^{2}$ & Düzeltilmiş $\mathbf{R}^{2}$ & \multicolumn{3}{c}{ Standart Tahmini Hata } \\
\hline 1 & \multicolumn{1}{c}{$0,565 \mathrm{a}$} & 0,320 & 0,306 & 23,854 & 0,73017 \\
\hline \multirow{2}{*}{ Model } & $\mathbf{2}$ & $\mathbf{S K 1}$ & Std. Error & $\begin{array}{c}\text { SK2 } \\
\text { Beta }\end{array}$ & $\mathbf{t}$ & $\mathbf{p}$ \\
& & 1,100 & 0,324 & & 3,399 & 0,001 \\
& \multirow{2}{*}{ Fiziki Görünüm } & 0,217 & 0,069 & 0,212 & 3,169 & 0,002 \\
& Güvenilirlilik & 0,148 & 0,075 & 0,120 & 1,975 & 0,049 \\
& Heveslilik & $-0,082$ & 0,119 & $-0,063$ & $-0,684$ & 0,495 \\
& Güven & 0,172 & 0,098 & 0,138 & 1,743 & 0,082 \\
& Empati & 0,315 & 0,068 & 0,336 & 4,610 & 0,000 \\
\hline
\end{tabular}

SK1: Standartlaştırılmamış Katsayılar, SK2: Standartlaştırılmış Katsayılar

Bağımlı değişken müşteri sakadati ile bağımsız değişken hizmet kalitesi boyutlarının oluşturduğu modelin bir bütün olarak anlamlı olduğu $(\mathrm{F}=23,854, \mathrm{p}<0,001)$ tespit edilmiştir. Fiziki görünüm, güvenilirlik ve empati faktörlerinin müşteri sadakatini pozitif yönde etkilediği saptanmıştır. Bu bilgiler 1şığında; H3a, H3b ve H3e hipotezlerinin desteklendiği, H3c ve H3d hipotezinin ise desteklenmediği sonucuna ulaşılmıştır.

\section{TARTIŞMA VE SONUÇ}

Hizmet kalitesi ürün ve hizmetlerinin müşteri tarafından değerlendirilmesi ile oluşan, işletmelerin sektördeki rekabet gücünü ve karlılığını önemli ölçüde etkileyen bir unsurdur. Havayolu taşımacıllğında hizmet kalitesi değerlendirilirken sadece uçuş süreci incelenmemekte; aynı zamanda uçuş öncesi ve sonrasını da ele alınmaktadır. Havayolu taşımacılığındaki hizmet kalitesi müşteri belliğindeki işletme algısını ve kurumsal imajı güçlendirmektedir. Yoğun rekabetin yaşandığı havacılık sektöründeki işletmelerin başarılı olmasında kurumsal imaj, müşteri memnuniyeti ve sadakati anahtar rol üstlenmektedir (Uyguç, 1998).

Literatürde farklı sektörlerde hizmet kalitesi, kurumsal imaj, müşteri memnuniyeti ve sadakati değişkenleri incelenmiştir, ama havayolu taşımacılığında bu dört değişkeni de ele alan bir çalışmaya rastlanılamamıştır. Bu çalışma ile literatüre katkı sağlanması öngörülmektedir. Bu çalışmada, havayolu taşımacılığında hizmet 


\section{G. Yanginlar - F. Tuna 12/1 (2020) 173-187}

kalitesinin kurumsal imaj, müşteri memnuniyeti ve müşteri sadakati üzerindeki etkilerini belirlenmesi amaçlanmıştır. Çalışmanın sonucunda, hizmet kalitesi alt boyutlarından güven ve empati ile kurumsal imaj arasında pozitif yönlü bir ilişki olduğu saptanmıştır. Hizmet kalitesinin heveslilik ve güven faktörleri dışında bütün alt faktörlerin müşteri memnuniyetini ve sadakatini pozitif yönde etkilediği görülmektedir.

Çalışmamızı destekler nitelikte birçok çalışma literatürde yer almaktadır. Yıldız ve Erdil (2013) çalışmalarında havayolu taşımacılığında hizmet kalitesini fiziksel görünüm, güvenirlik, heveslilik, güven ve empati başlıkları altında değerlendirmiştir. Çelikkol ve diğ. (2012) çalışmalarında, Türkiye'deki iç hat havayolu taşımacılığında müşteri memnuniyeti yaratan unsurların hizmet kalitesi, rahatlık, konfor ve güvenlik olduğu sonucuna ulaşılmıştır. Karapınar ve Akgül (2015) hizmet kalitesi boyutlarından en çok güvenirlik, daha sonra empatinin kurumsal imajı olumlu yönde etkilediğini saptamıştır.

Bunun yanısıra; Taşkın ve Gönüller (2018) çalışmalarında güvenirlik ilkesinin müşteri memnuniyeti üzerinde, müşteri memnuniyetinin de müşteri sadakati üzerinde pozitif yönlü bir etkisi olduğunu yapısal eşitlik modeli ile kanıtlanmıştır. Özkan ve Yıldız (2008) çalışmasında müşteri sadakatini etkileyen önemli faktörlerin hizmet kalitesi ve müşteri memnuniyeti olduğunu ileri sürmektedir. Eroğluer (2013) çalışmasında hizmet kalitesinin fiziksel özellikler ve güven boyutlarını kurumsal imaj üzerinde pozitif yönlü; güvenirlik, empati, heveslilik boyutlarının ise negatif yönlü bir etkileri olduğu belirlenmiştir. Durgun ve Menteş (2016) çalışmalarında hizmet kalitesinin alt faktörlerinden materyaller ile iletişim \& problem çözmenin ve fiziksel görünümün müşteri memnuniyetini arttırdığı, hizmet kalitesi ile kurumsal itibar arasında pozitif yönlü bir ilişkinin olduğunu tespit edilmiştir. Kılıç ve diğ. (2013) çalışmalarında ise, hizmet kalitesi açısından müşteriler hizmetleri departmanının müşteri şikayetlerini ve taleplerini dikkate almasının müşteri sadakati yarattığına vurgu yapmaktadırlar.

$\mathrm{Bu}$ çalışmanın örnekleminde, uluslararası tanınırlığa sahip havayolu işletmesinin İstanbul havalimanındaki dış hat yolcuları olması bir kısıt oluşturmaktadır. Elde edilen sonuçların tüm havayolu taşımacılık sektörü için genellenmesi mümkün değildir. Gelecek çalışmalarda, havayolu, denizyolu, karayolu, demiryolu taşımacılığındaki hizmet kalitesinin Servqual yöntemi ile ölçülmesi ve karşılaştırma yapılması planlanmaktadır.

\section{KAYNAKLAR}

Andaleeb, S. S. and Conway, C. (2006). Customer Satisfaction in the Restaurant Industry: An Examination of the Transaction-Specific Model. Journal of Services Marketing, 20(1):3-11.

Arendt, S. and Brettel, M. (2010). Understanding the Influence of Corporate Social Responsibility on Corporate Identity, Image, and Firm Performance. Management Decision, 48(10):1469-1492.

Ataman, G., Behram, N.K. ve Eşgi, S. (2011). İş Amaçlı Havayolu Pazarında Hizmet Kalitesinin Servqual Modeli İle Ölçülmesi ve Türk Hava Yolları ‘Business Class' Yolcuları Üzerine Bir Araştırma. Selçuk Üniversitesi Sosyal Bilimler Enstitüsü Dergisi, 26:73-87.

Ay, G. ve Uçar, M. (2016). Trimester Eğitim Uygulamalarında Algılanan Hizmet Kalitesinin Ölçülmesi: Naci Topçuoğlu Meslek Yüksekokulu Büro Yönetimi ve Yönetici Asistanlığı Programı Öğrencileri ve Mezunları Üzerine Yapılan Bir Çalışma. Gaziantep University Journal of Social Sciences, 15(2):657-673.

Balcı, A. (2007). Sosyal Bilimlerde Araştırma Yöntem, Teknik ve Illkeler, Pegem Akademi Yayıncllı, Ankara.

Başol, S. (2012). Havayolu Yönetimi. Ekin Yayıncılık, Bursa.

Bolat, O. İ. (2006). Konaklama İşletmelerinde Kurumsal İmaj Oluşturma Süreci. Balıkesir Üniversitesi Sosyal Bilimler Enstitüsü Dergisi, 15:107-126.

Bove, L.L., Pervan, S.J. and Beatty, S.E. (2009). Service Worker Role in Encouraging Customer Organizational Citizenship Behavior. Journal of Business Research, 62:698-705.

Canöz, N. (2017). Türkiye'deki Havayolu İşletmelerinin Hizmet Anlayışlarının Belirlenmesine Yönelik Bir Araştırma. Selçuk Üniversitesi Sosyal Bilimler Meslek Yüksekokulu Dergisi, 20(2):192-205.

Chang Y.H. and Yeh C.H. (2002). A Survey Analysis of Service Quality for Domestic Airlines. European Journal of Operational Research, 139:166-177.

Chattananon, A., Lawley, M., Supparerkchaisakul, N. and Leelayouthayothin, L. (2008). Impacts of a Thai cause-related Marketing Program on Corporate Image. International Journal of Emerging Markets, 3(4):348-363. 


\section{G. Yanginlar - F. Tuna 12/1 (2020) 173-187}

Çalıyurt, K. (2012). Havayolu Kurumsal Yönetim ve Bağımsız Denetim. Ekin Yayıncılık, Bursa.

Çatı, K. ve Koçoğlu, C.M. (2008). Müşteri Sadakati İle Müşteri Tatmini Arasındaki İlişkiyi Belirlemeye Yönelik Bir Araştırma. Selçuk Üniversitesi Sosyal Bilimler Enstitüsü Dergisi, 19:167-188.

Çelikkol, E.S., Uçkun, C.G., Tekin, V.N. ve Çelikkol, Ş. (2012). Türkiye'de İç Hatlardaki Havayolu Taşımacılığında Müşteri Tercihi ve Memnuniyetini Etkileyen Faktörlere Yönelik Bir Araştırma. İşletme Araştırmaları Dergisi, 4(3):70-81.

Çınaroğlu, S. ve Şahin, B. (2012). Kurumsal İtibar ve İmajın Hastanelerin Performansı ile İlişkisi. Hacettepe Üniversitesi İktisadi ve İdari Bilimler Fakültesi Dergisi, 30(2):27-56.

Çobanoğlu, E. ve Baykal B. (2013). Türk Otomotiv Sektöründe Kurumsal Marka Kişiliğinin Müşteri Memnuniyeti ve Müşteri Sadakati Üzerine Etkileri. İstanbul Üniversitesi İşletme Fakültesi İktisadi Enstitüsü Yönetim Dergisi, 24(74):52-85.

Duygun, A. ve Menteş, S.A. (2016). Kurumsal İtibar ve Hizmet Kalitesinin Müşteri Memnuniyeti Üzerine Etkileri: İstanbul'da Alışveriş Merkezlerinde Bir Araştırma. Business \& Management Studies: An International Journal, 4(2):125-141

Emir, O., Kılıç, G. ve Pelit, E. (2010). Üç Yıldızlı Otel İşletmelerinde Müşteri Memnuniyeti Üzerine Bir Araştırma. Süleyman Demirel Üniversitesi İktisadi ve İdari Bilimler Fakültesi Dergisi, 15(3):291-310.

Eroğlu, K. (2013). Hizmet Kalitesi Algısının Kurumsal İmaja Etkisi Üzerine Hizmet Sektöründe Bir Araştırma. Anadolu Üniversitesi Sosyal Bilimler Dergisi, 13(4):29-46.

Gilberta D. and Wong R.K.C. (2003). Passenger Expectations and Airline Services: a Hong Kong Based Study. Tourism Management, 24:519-532.

Gowan M., Seymour J., Ibarreche S. and Lackey C. (2001). Service Quality in a Public Agency: Same Expectations but Different Perceptions by Eemployees, Managers and Customers. Journal of Quality Management, 6(2): 275-291.

Guo, Xin., Duff A. and Hair, M. (2008). Service Quality Measurement in the Chinese Corporate Banking Market. International Journal of Banking Marketing, 26(5):305-327.

Görkem, O. ve Yağcı, K. (2016). Hava Yolu Yolcularının Kabin içi Hizmet Algılarının Değerlendirmesi: Türk Hava Yolları Örneği. İşletme Araştırmaları Dergisi, 8(1):432-447.

Gray, E.R. and Balmer, J.M.T. (1998). Managing Corporate Image and Corporate Reputation. Long Range Planning, 31(5):695-702.

Gülseven, O., Aycan, A. ve Uçan, Y. (2012). Basketbol Seyircilerinin Spor Salonlarının Hizmet Kalitesi Alg1S1 ve Özdeşmişlik Durumlarının İncelenmesi. Beden Eğitimi ve Spor Bilimleri Dergisi, 14(2):1-13.

Gürsoy, D., Chen, M.H. and Kim, H.Y. (2005). The US Airlines Relative Positioning Based on Attributes of Service Quality. Tourism Management, 26(1):57-67

Hatipoğlu, S. ve Işık, E.S. (2015). Havayolu Ulaşımında Hizmet Kalitesinin Ölçülmesi: İç Hatlarda Bir Uygulama. Kocaeli Üniversitesi Sosyal Bilimler Dergisi, 12(2):293-312.

Hussain, R., Nasser, A. A. and Hussain Y. K. (2014). Service Quality and Customer Satisfaction of a UAEBased Airlines: An Empirical Investigation. Journal of Air Transport Management, 1-9.

Jacobson, B.G. and Abratt, M.C. (2003). The Corporate Identity Process Revisited. Journal of Marketing Management, 19:835-855.

Kalyoncuoğlu, S. (2017). Markaya Duyulan Güven ile Marka Sadakati İlişkisinde Marka Aşkının Aracılık Rolü: Starbucks Markası Üzerine Bir Araştırma. Journal of Tourism and Gastronomy Studies, 5(4):383-402.

Karacan, S. ve Kaya, M. (2011). Lojistik Faaliyetlerde Maliyetleme. Umuttepe Yayıncllı, Kocaeli.

Karadeniz, M. ve Demirkan, G. (2015). Perakende Mağazacılık Sektöründe Hizmet Kalitesinin Marka Sadakati Üzerine Etkisi: Bir Araştırma. Celal Bayar Üniversitesi Sosyal Bilimler Dergisi, 13(2):245-262.

Karadeniz, M. ve Ünver, N.M. (2014). Şehir İçi Denizyolu Ulaşımında Müşterilerin Hizmet Algısı ve Memnuniyeti: Bir Uygulama. Öneri Dergisi, 11(42):43-68.

Karapınar, E.S. ve Akgül, H. (2015). Okul Öncesi Eğitim Kurumlarında Algılanan Hizmet Kalitesi ve Kurumsal İmajın Birbirine Etkisi. İşletme Araştırmaları Dergisi, 7(4):225-250. 


\section{G. Yanginlar - F. Tuna 12/1 (2020) 173-187}

Kazançoğlu, Y. ve Kazançoğlu, İ. (2013). Benchmarking Service Quality Performance of Airlines in Turkey. Eskişehir Osmangazi Üniversitesi İktisadi ve İdari Bilimler Dergisi, 8(1):59- 91.

Keskin, H.M. (2015). Tedarik Zinciri Yönetimi. Nobel Yayıncılık, Ankara.

Kılıç, B., Ok, S. ve Sop, S.A. (2013). Otel İşletmelerinde Müşteri Şikayetlerinin Değerlendirilmesi ve Hizmet Kalitesi Algisının Müşteri Sadakati Üzerine Etkisi. Gaziantep University Journal of Social Sciences, 12(4):817-836.

Kim, W.G., Christy, Y. N. and Yen-Soon K. (2009). Influence of Institutional Dineserv on Customer Satisfaction, Return Intention and Word-of Mouth. International Journal of Hospitality Management, 28(1):10-17.

Kim, K.J., Jeong, I.J., Park, J.C., Park, Y.J., Kim, C.G. and Kim, T.H. (2007). The Impact of Network Performance on Customer Satisfaction and Loyalty: High-Speed Internet Service Case in Korea. Expert Systems with Applications, 32:821-831.

Koban, E. ve Keser, H.Y. (2011). Dış Ticarette Lojistik. Ekin Yayıncılık, Bursa.

Koçak, F. (2014). Öğrenci Görüşlerine Göre Spor Öğretimi Veren Yükseköğretim Kurumlarının Kurumsal İmaj1. Spormetre Beden Eğitimi ve Spor Bilimleri Dergisi, 12(1):71-80

Kotler, P. and Armstrong, G., (2009). Marketing: an Introduction. Upper Saddle River, Pearson Education, New York.

Küçükoğlu Tepe, M. ve Pınar, R.İ. (2015). Effect of CRM's Critical Success Factors on Company Performance. Management Studies, 3(1-2):41-49.

Lee, S., Cho, W.H., Choi, K.S. and Kang, M. (2001), Comparative Analysis of Models for Measuring Consumer Satisfaction in Health Care Organization. Korean J. Prev Med., 34(1):55-60.

Lin, H. and Wang, Y. (2006). An Examination of The Determinants of Customer Loyalty in Mobile Commerce Context. Information Management, 43:271-282.

Mohammad, A.A.S. and Alhamadani, S.Y.M. (2011). Service Quality Perspectives and Customer Satisfaction in Commercial Banks Working in Jordan. Euro Journals Publishing, (14):60-72.

Murdick, R.G., Render, B. and Russel, S. (1990). Service Operations Management. Allyn and Baco, America.

Okumuş, A. ve Asil, H. (2007). Hizmet Kalitesi Algılamasının Havayolu Yolcularının Genel Memnuniyet Düzeylerine Olan Etkisinin İncelenmesi. İstanbul Üniversitesi İşletme Fakültesi İşletme Dergisi 36(2):0729.

Özer, Ö. ve Günaydın, Y. (2010). Otel İşletmelerinde Müşteri Memnuniyeti ve Müşteri Sadakati İlişkisi: Dört Yıldızlı Otel İşletmelerinde Bir Uygulama. İşletme Fakültesi Dergisi, 11(2):127-154.

Özgözgü, S. (2016). Kurumsal İmaj, Örgüt Kültürü ve Örgütsel Özdeşleşme İlişkisi. Kastamonu Eğitim Dergisi, 25 (2):581-596.

Özgüven, N. (2008). Hizmet Pazarlamasında Müşteri Memnuniyeti ve Ulaştırma Sektörü Üzerinde Bir Uygulama. Ege Akademik Bakış, 8(2): 651-682.

Özkan, E. ve Yıldız, S.(2008). Müşteri Sadakati ile Ağızdan Ağıza İletişiminin Tüketici Satın Alma Davranışlarına Etkisi: Elektronik Eşya Sektöründe Bir Uygulama. Uluslararası İktisadi ve İdari Incelemeler Dergisi, 4:359-381.

Parasuraman, A., Zeithalm, V.A. and Berry, L.L., (1985). A Conceptual Model of Service Quality and Its Implications for Future Research. Journal of Retailing, 64:12-40.

Pişgin, A. ve Ateşoğlu, İ. (2015). Sağlık Kurumlarında Müşteri Memnuniyeti ve Değiştirme Maliyetlerinin Müşteri Sadakati Üzerindeki Etkileri. İşletme Araştırmaları Dergisi, 7(4):251-271.

Prasad M. D. and Shekdar, B.R. (2010). Development of Railqual: A Service Quality Scale for Measuring Indian Railway Passenger Services. Management Science and Engineering 4(3):87-94.

Rahaman K.R. and Rahaman, A. (2009). Service Quality Attributes Affecting the Satisfaction of Railway Passengers of Selective Route in Southwestern Part of Bangladesh. Theoretical and Empirical Researches in Urban Management, 3(12):115-125.

Skandri, H., Mouelhi, N. and Malek, F. (2011). Effect of Store Atmospherics on Employees' Reactions. International Journal of Retail \& Distribution Management. 39(1):51-67. 


$$
\text { G. Yanginlar - F. Tuna 12/1 (2020) 173-187 }
$$

Seçilmiş, C., Kaşlı, M., Kılıçlar, A.V.ve Sarı, Y. (2001). Demiryolu Hizmetlerindeki Kalitenin Ödenen Ücret Açısından Müşteri Tatminine Etkisi. Ege Akademik Bakış, 11(4):573-586.

Serçek, G.Ö. ve Serçek, S. (2016). Otel Misafirperverliği Algısının Müşteri Memnuniyeti Üzerine Etkisi: Yabancı Turistler Üzerine Bir Araştırma. İşletme Araştırmaları Dergisi, 8(4): 140-161.

Şen, L.M. ve Akpur, A. (2017). Düşük Maliyetli Bir Havayolu İşletmesinde Uçak İçi Hizmetler Kalite Algısını Ölçmeye Yönelik Bir Araştırma. İşletme Araştırmaları Dergisi, 9(4):63-83.

Taslak, S. ve Akın, M. (2005). Örgüt İmajı Üzerinde Etkili Olan Faktörlere Yönelik Bir Araştırma: Yozgat İli Emniyet Müdürlüğü Örneği. Sosyal Bilimler Enstitüsü Dergisi, 19(2):263-294.

Taşkın, E. ve Durmaz, Y. (2012). Lojistik Faaliyetler. Detay Yayıncılık, Ankara.

Taşkın, Ç. ve Gönüller, Ş. (2018). Satış Sonrası Hizmetlerde Müşteri Sadakatinin Öncülleri: Mercedes Otomobil Markası Üzerine Bir Araştırma. Yönetim Bilimleri Dergisi, 16(32):113-134.

Taşliyan, M., Paksoy, H.M. ve Hırlak, B. (2013). Gaziantep University Journal of Social Sciences 12(4):775-805.

Tiernan, S. and Dawna, L.W. Jr, B. (2008). Airline Service Quality: Exploratory Analysis of Consumer Perceptions and Operational Performance in the USA and EU, Managing Service Quality, 18(3):212224.

Tsaur, S.H., Chiu, Y.C. and Huang, C.H. (2002). Determinants of Guest Loyalty to International Tourist HotelsA Neural Network Approach. Tourism Management, 23:397-405.

Uyguç, N. (1998). Hizmet Sektöründe Kalite Yönetimi-Stratejik Bir Yaklaşım. Eylül Yayınları, İzmir.

Yavuz, Ş. (2010). Kurumsal Sosyal Sorumluluğun Kurumsal İmaj ve Satın Alma Kararı Üzerindeki Etkileri. Selçuk İletişim, 6(3):100-110.

Yeung, M.C.H. and Ennew, C.T., (2000). From Customer Satisfaction To Profitability. Journal Of Strategic Marketing, 8:313-326.

Yıldırır, S.C. (2015). Havayolu Taşımacılığında Rekabet Unsurlarının Değişkenliği ve Hizmet İnovasyonu İle Müşteri Memnuniyetinin Artırılması: Yeni Bir "Mil+Süre Puanı" Uygulaması. İşletme Araştırmaları Dergisi, 7(1):340-359.

Yıldız, O. ve Erdil, T.S. (2013). Türkiye Havayolu Yolcu Taşımacılığ Sektöründe Hizmet Kalitesinin Karşılaştırmalı Ölçümlenmesi. Öneri Dergisi, 10(39):89-100.

Yıldız, S. ve Tehci, A. (2014). Ağızdan Ağıza İletişimde Müşteri Tatmini ve Müşteri Sadakati ile Mağaza İmajı Boyutlar1: Ordu İlinde Bir Uygulama. Atatürk Üniversitesi Sosyal Bilimler Enstitüsü Dergisi, 18(1):441460

Yılmaz, V. ve Filiz, Z. (2007). Servqual Yöntemiyle Yükseköğretimde Hizmet Kalitesinin Ölçülmesi. Anadolu Üniversitesi Sosyal Bilimler Dergisi, 7(1):299-316.

Yurdakul, M. (2007). İlişkisel Pazarlama Anlayışında Müşteri Sadakati Olgusunun Ayrıntılı Bir Şekilde Analizi. Dumlupinar Üniversitesi Sosyal Bilimler Dergisi, 17:268-287.

Zeithaml, V.A. and Bitner, M.J. (2003). Services Marketing: Integrating Customer Focus Across the Firm. McGrawHill, Boston. 